\title{
Training marketing by German companies. Which training place characteristics are communicated?
}

\author{
Margit Ebbinghaus* \\ Federal Institute for Vocational Education and Training, Vocational Education and Training, \\ Supply and Demand/Training Participation Division, Robert-Schuman-Platz 3, 53175 Bonn
}

Received: 20.07.2018; Accepted; 08.02.2019; Published: 29.08.2019

\begin{abstract}
Context: Although the German dual system of vocational education and training makes a major contribution to securing the supply of skilled workers for trade and industry, its function has been under scrutiny for several years. Companies are finding it increasingly difficult to recruit trainees, and increasing numbers of training places are vacant. However, such recruitment problems tend to be concentrated in certain occupations rather than occurring across all sectors equally. This has led to a significant increase in competition among companies seeking to secure the services of trainees in various occupations and calls into question the extent to which such fierce rivalry is reflected in the type of training marketing they conduct.
\end{abstract}

Approach: This paper investigates the training place characteristics companies communicate in their advertisements. Among these characteristics, differences exist in the general conditions of training, requirements for trainees and incentives the companies provide. Latent class analyses were used to investigate the patterns revealed in the training place characteristics and to examine if the frequency with which patterns occur correlates with whether a company is seeking trainees for an occupation with or without recruitment problems and with company size. The analyses were based on data collected from 1,939 small and medium-sized enterprises via standardised telephone interviews conducted at the beginning of 2016. The companies in question had offered training places in one of nine selected dual occupations. Four of the training occupations considered have recruitment problems. There are no recruitment difficulties in the other five.

*Corresponding author: ebbinghaus@bibb.de

ISSN: $2197-8646$

http://www.ijrvet.net

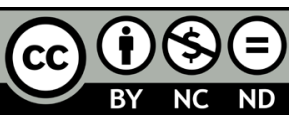


Findings: The single group latent class analysis initially conducted resulted in a model with three latent classes exhibiting clearly differentiated patterns of training place characteristics. As well as focusing on general conditions and the requirements for training, the "aggressive" pattern mainly emphasises the incentives the training place or company offered. The "requirements-oriented" pattern concentrates on the future requirements for trainees. The "basic" pattern communicates only a very few fundamental training place characteristics. A subsequent multi-group latent class analysis revealed evidence that small and medium-sized enterprises offering training are more likely to display an aggressive pattern in occupations with recruitment problems than SMEs providing training in occupations where there are no recruitment difficulties. By the same token, small and medium-sized enterprises with training provisions in occupations with recruitment problems are less likely to exhibit training marketing aligned to the requirements of applicants than firms offering training in occupations without recruitment difficulties, although this is significantly clearer amongst small companies than medium-sized companies. Nevertheless, the class with requirementsoriented marketing constitutes the largest class for all four company groups.

Conclusion: The results indicate that conditions in the training market affect the training marketing companies carry out. However, they also show that companies are more likely to use their training marketing to react to recruitment problems that have already occurred rather than take a preventative approach towards such difficulties. For small companies in particular, the limitations in resources available for more elaborate training marketing likely contribute to this approach. Nevertheless, further research is needed to consolidate the outcomes identified here.

Keywords: German system of dual vocational education and training, recruitment problems, training marketing, latent class analysis, VET

\section{Introduction}

Dual vocational education and training is an important location factor for German trade and industry. The majority of persons making up the labour demand in Germany is in possession of a dual vocational qualification ${ }^{1}$. Such a qualification is acquired by completing a training programme that is mostly of a duration of between three and three and a half years. During this period, occupational skills, knowledge and competencies obtained via practical work at the company for three to four days per week are supplemented by teaching at a vocational school on one to two days per week. Although vocational schools are involved in the vocational education and training, the training contract governing this type of employment for

1 cf. https://www.destatis.de/DE/ZahlenFakten/GesellschaftStaat/BildungForschungKultur/Bildungsstand/Tabellen/Bildungsabschluss.html 
training purposes is solely concluded between the company and the young person on the basis of the Vocational Training Act (Berufsbildungsgesetz).

Training contracts are thus entered into as a result of supply and demand in the same way as contracts of employment (cf. inter alia Herkner, 2013, p. 1). Companies offer their training places on the market and use criteria which they are largely free to stipulate for themselves to select their future trainees from the young people who have submitted an application. The number of training places in companies is primarily geared to their own demand for skilled labour. At the same time, securing one's own demand for skilled workers is the most important reason why German companies participate in dual vocational education and training (Merrilees, W. J. 1983; Niederalt 2005; Jansen, Pfeifer, Schönfeld \& Wenzelmann, 2015, Gessler 2017).

However, this route towards securing a supply of skilled workers is increasingly creating difficulties for companies in Germany. School leaver numbers are falling due to demographic reasons, and young people are increasingly attracted by universities and universities of applied sciences. The consequence of this is that fewer and fewer young people are applying for the training places on offer. As a result, recent years have seen a continuous rise in the proportion of companies affected by recruitment problems because they are unable to fill or completely fill their training vacancies. In $2016,45.4 \%$ of the companies reported such problems (Troltsch, 2017a, pp. 232-233).

Considerable differences between the individual occupations encompassed by dual vocational education and training are behind this general development. Whereas particularly marked recruitment problems exist in occupations connected with the hotel and restaurant trade and in traditional craft trade occupations (such as baker), these difficulties are significantly less pronounced in occupations in the media, commercial and technical sectors (for example mechatronics fitter) (Matthes, Ulrich, Flemming \& Granath, 2017, pp. 25-27).

Although it has become harder in overall terms for companies to find apprentices, the main effect has been to create considerably tougher competition between firms seeking to acquire interested young people for different training occupations. This poses the question as to the extent to which such fiercer rivalry is reflected in the type of training marketing they conduct. The present paper investigates this issue with regard to the characteristics communicated by companies in respect of the training places they offer. It looks at which training place characteristics are emphasised by companies within the scope of their training marketing and examines the extent of significance of the training occupation for which applicants are being sought. Section 2 provides a theoretical and empirical alignment for the investigation. It begins by outlining possible explanations for recruitment problems which vary according to the specific occupation (2.1) before moving on to outline approaches as to how training marketing could be used to counter these difficulties whilst placing the emphasis on contents communicated (2.2). Section 3 describes the database deployed to address the issues 
and delineates the analytical methods and stages. Section 4 reports on the results obtained, and these are subsequently discussed in the final Section (5).

\section{Theoretical and empirical points of reference}

\subsection{Problems with the filling of training places which vary in an occupa- tional-specific way}

The difficulties of recruiting apprentices differ between individual dual training occupations and may be viewed as the result of career choice behaviour on the part of young people. Various models (including Esser 1999, Gottfredson 2002) have approached this elective behaviour on the basis of the expectancy theory of motivation (Vroom 1964). The core assumption of the models is that two aspects affect the occupational choice and therefore also affect the application behaviour of young people. The first of these is the value or attractiveness of an occupation. The second aspect relates to the occupational expectations.

The value or attractiveness of an occupation refers to the extent to which the tasks correspond to individual preferences (e.g. Holland's six personality traits; Holland 1966), but also to the extent to which the occupation serves personal aspirations in terms of goals (Rojewski 2005), such as gaining social prestige through the occupation (Gottfredson 2002). A couple of studies indicate that aspirations, particularly prestige, influence occupational choice more strongly than tasks (Farmer, Rotella, Anderson \& Wardrope 1998; Rojewski \& Kim 2003; Eberhard, Scholz \& Ulrich 2009; Steinritz, Kayser \& Ziegler 2012).

Occupational expectations refer to the assumed chances of getting access to an attractive occupation. According to Esser (1999) those expectations are materially dependent on the circumstances on the training market (Esser 1999, pp. 251-259). A high degree of competition between young people seeking a training place lessens occupational expectations whereas a high number of unfilled training places increases occupational expectations. In other words: If market conditions are less favourable young people will shift their aspirations towards more accessible - but most of the time less attractive - occupations such as occupations in the craft trades (Kaiumov, Kanikov \& Iskhakova 2014). Otherwise they will draw their attention on occupations which enjoy greater social recognition like occupations in the fields of media, administration and organisation (ibid.; also NORC's studies of occupational prestige by Smith \& Son 2014), because they appear to be well within reach. The statistics of the German training market confirm these mechanisms. Parallel to the decrease in the overall number of applicants during the recent years the number of young people seeking a training place in the occupation of baker has, for example, fallen rapidly. By way of contrast, 
applicant numbers for training places in the occupation of mechatronics fitter are even tending to show an increase (BIBB survey as of 30 September).

Compared to the significance of the occupation, there has been very little consideration to the importance of the company within the context of explaining the application behaviour of young people towards training places offered in Germany ${ }^{2}$. Within this context, expectancy theory can also be used to argue that young people prefer to apply to companies which offer them something which they perceive to be of high value. According to generational theory (Mannheim 1952, Howe \& Strauss 1991), nowadays most of the training seekers belong to Generation Z. While the period of time used to define this generation differs between studies and papers (e. g. born as from 1995, 2000 or 2005) some work related characteristics of Generation $\mathrm{Z}$ members are reported quite consistent. They are described as being highly interested in security of employment as well as in fast career opportunities, they are attentive to work-life balance, like spaces located near their homes and appreciate order, structure and predictability in their lives (inter alia Stillman \& Stillman 2017 pp. 139-170 and pp. 248-272; Hurrelmann 2016, pp. 4-9).

Taking this into account, young people should be more likely to apply for a training place if a company possesses attributes that go along with their work related desires. Furthermore, there are some indications that these characteristics even increase the incentive to apply for training in an occupation different to that which the young person in question originally aspired to enter (Gei \& Eberhard 2017, pp. 260-261). In other words, young people may sometimes find it more desirable to seek training at an attractive company rather than in a certain occupation. The prerequisite is, however, that the company must be perceived as an attractive employer or provider of training, and this draws attention to the training marketing that it conducts.

\subsection{Training marketing for the acquisition of applicants}

Training marketing may be viewed as a special form of human resources marketing. Due to an increasingly competitive labour market human resource marketing gained attention among scholars and practitioners (e.g. Boxall 1998; Backhaus and Tikoo 2004; Mosley 2015). The essential aim of human resource marketing is to establish a company as an employer of choice in such a way so as to arouse the wish in targeted job seekers to attend this company and if possible no other (e.g. Backhaus \& Tikoo 2004, pp. 502-505; Berthon, Ewing \& Hah 2005, pp. 151-152; Edwards 2010, pp. 6-7). Human resources marketing therefore needs to provide targeted potential employees with information they need to consider applying for a job. Communication measures are indispensable in this regard. Within the context of filling

2 Quite a different thing applies within the context of filling positions for skilled workers and management staff. In this case, a significantly higher degree of importance is attached to the choice of company or employer by researchers, including in Germany (cf. inter alia Feldmann \& Arnold 1978; Böckenholt \& Homburg 1990; Lieber 1995). 
positions for skilled workers and management staff a variety of studies has focussed on 'classical' formal and informal communication channels, such as job advertisements in newspapers and word-of-mouth, that are used by companies to communicate their positions (e.g. Mencken \& Winfield 1998; Breaugh \& Starke 2000; Allen, Van Scotter \& Otondo 2004; Van Hoye 2012). Findings indicate that job seekers are more attracted through informal recruiting sources than through formal communication channels (e.g. Collins \& Stevens 2002; Van Hoye \& Livens 2009) ${ }^{3}$. As far as training places are concerned, the few studies available suggest that craft enterprises tend to communicate training offers via informal channels, whereas companies from industry and commerce more frequently choose formal channels (Gerhards \& Ebbinghaus 2014, pp.9-14).

Another aspect of human resource marketing concerns the information contained in employment advertisements. Theoretically speaking, advertisements may be viewed as conglomerates of information about the Position as a product (inter alia Freimuth 1989, p. 43; Brast, Holtgrave \& Flindt 2017, pp. 38-39). Such information can relate to general conditions, to requirements made of applicants, or to incentives offered by the company.

Various studies indicate that the kind of information provided in employment advertisements have an impact on the decision to apply (inter alia Feldman, Bearden \& Hardesty 2006; Born \& Taris 2010; Wille \& Derouse 2018). Following on from this, there is now also a wide range of guidebook literature which emphasise that it is simply impossible to overstress the importance of communicating the conditions and benefits of the training place on offer given the current state of affairs on the German training market in general and recruitment problems in particular (inter alia Beck \& Dietl 2014). In addition, there are various websites, blogs and platforms on the subject of training marketing (e.g. ausbildungsmarketing.com). In contrast to this, however, only little is known so far about which information companies in Germany provide in advertisements about the training places they offer. While these studies indicate that companies tend to concentrate more on general conditions than on incentives but also suggest that the latter have gained a greater degree of significance lately (Eisele \& Ziegler 2013; Association of German Chambers of Commerce and Industry 2017, pp. 12-14), there is no clarity as to the extent to which this constitutes a general phenomenon or whether it is simply the case that particularly companies seeking trainees in occupations where there are recruitment problems are making greater use of incentives in their training marketing. The combination of characteristics communicated by the companies is a further unresolved issue. The aim of the present paper is to deliver findings in this regard. In specific terms, it investigates a) the extent to which training place characteristics communicated by the companies within the scope of their training marketing exhibit certain patterns and $b$ ) whether there is a correlation between these patterns and the training occupation in which places are

3 Meanwhile the focus of research has shifted towards recruiting techniques using company web sites and social media (e.g. Van Hoye \& Lievens 2007; Kluemper, Mitra \& Wang 2016; Wordaz 2018). 
being offered or apprentices sought. Latent class analyses (LCA) are conducted in order to expose such patterns and correlations. More details of these and of the database used for the analyses are provided in the following section.

\section{Data and methods}

\subsection{Sample}

The data used was collected via telephone at the beginning of 2016 from small and mediumsized enterprises (1 to 249 employees) located in Germany which were offering at least one training place for the training year 2015/2016 ${ }^{4}$ in one of nine selected occupations within the dual system of vocational education and training in Germany (cf. Table 1). We chose to focus on SMEs to take account of the circumstance that $99 \%$ of all companies providing training in Germany fall within these size categories (cf. inter alia Troltsch 2017b, p. 216) and in light of the fact that firms of this order of magnitude are more likely to face recruitment problems than major companies (cf. Troltsch 2017a, pp. 232-233).

The nine training occupations included are in all cases amongst the most significant in the dual system in terms of the numbers of trainees learning the occupations (cf. BIBB survey as of 30 September - Table 67/2015). All nine are also craft trades or trade and industry occupations and thus fall within the main dual VET sectors. There are, however, significant differences with regard to the ratio between numbers of applicants and numbers of training places offered (supply-demand ratio, SDR) and in respect of the amount of training places that remain unfilled as a proportion of all places offered (vacancy rate, VR) (cf. Table 1).

These indicators, which formed the basis for selection of the occupations alongside size and economic sector, show that two of the occupations selected (baker, restaurant specialist) already had far fewer applicants than training places offered at the beginning of the threeyear period of observation. In the case of two further occupations (plant mechanic for sanitary, heating and air conditioning systems [SHK], hairdresser), the same situation entered into force during the period of observation itself. These four occupations are therefore affected by considerable recruitment difficulties, something which is also reflected in the vacancy rate, and have accordingly been conflated into a group of occupations with recruitment problemsfor the purpose of further analysis. In the case of the five other occupations, the number of applicants continues to exceed the number of training places on offer. In one instance (management assistant for retail services), demand outstrips supply considerably, and in another (information technology specialist), the tendency towards excess demand is growing. At the same time, companies were largely successful in obtaining applicants to fill the places on offer

4 The training year in Germany usually commences on 1 August or 1 September. 
in these occupations. Vacancy rates are significantly lower than in the four comparison occupations and are also mostly lower than the average across all occupations in the dual system. In the following analyses, these five occupations accordingly form the group of occupations without recruitment problems.

Table 1: Occupational-related training market indicators for the training years 2013 to 2015

\begin{tabular}{|c|c|c|c|}
\hline Training occupation & Year & SDR & VR \\
\hline \multirow{3}{*}{$\begin{array}{l}\text { Plant mechanic for sanitary, heating and air } \\
\text { conditioning systems }(\mathrm{CT}, \mathrm{TI})\end{array}$} & 2013 & 100.9 & 5.9 \\
\hline & 2014 & 99.6 & 6.5 \\
\hline & 2015 & 98.3 & 7.8 \\
\hline \multirow[t]{3}{*}{ Baker (CT, TI) } & 2013 & 84.7 & 22.3 \\
\hline & 2014 & 81.0 & 25.3 \\
\hline & 2015 & 79.5 & 26.6 \\
\hline \multirow{3}{*}{$\begin{array}{l}\text { Electronics technician for industrial engineering } \\
(\mathrm{TI}, \mathrm{CT})\end{array}$} & 2013 & 103.4 & 4.0 \\
\hline & 2014 & 102.7 & 4.5 \\
\hline & 2015 & 103.1 & 3.8 \\
\hline \multirow[t]{3}{*}{ Information technology specialist (TI, CT) } & 2013 & 113.8 & 3.8 \\
\hline & 2014 & 116.7 & 3.1 \\
\hline & 2015 & 117.1 & 4.1 \\
\hline \multirow[t]{3}{*}{ Hairdresser (CT) } & 2013 & 102.0 & 11.0 \\
\hline & 2014 & 98.8 & 12.9 \\
\hline & 2015 & 98.4 & 12.7 \\
\hline \multirow[t]{3}{*}{ Insurance and financial services broker (TI) } & 2013 & 102.3 & 4.7 \\
\hline & 2014 & 103.1 & 4.3 \\
\hline & 2015 & 102.0 & 5.8 \\
\hline \multirow{3}{*}{$\begin{array}{l}\text { Management assistant for retail services (TI, } \\
\mathrm{CT} \text { ) }\end{array}$} & 2013 & 114.5 & 8.7 \\
\hline & 2014 & 115.8 & 7.1 \\
\hline & 2015 & 113.6 & 8.8 \\
\hline \multirow[t]{3}{*}{ Mechatronics fitter (TI, CT) } & 2013 & 105.9 & 3.0 \\
\hline & 2014 & 104.1 & 3.5 \\
\hline & 2015 & 103.1 & 4.6 \\
\hline \multirow[t]{3}{*}{ Restaurant specialist (TI, CT) } & 2013 & 76.4 & 30.0 \\
\hline & 2014 & 72.2 & 33.8 \\
\hline & 2015 & 69.9 & 34.9 \\
\hline \multirow[t]{3}{*}{ All occupations in the dual system } & 2013 & 108.8 & 6.0 \\
\hline & 2014 & 107.9 & 6.6 \\
\hline & 2015 & 107.0 & 7.4 \\
\hline
\end{tabular}

SDR = supply-demand ratio, number of applicants per 100 training places offered, VR = vacancy rate, number of unfilled training places as a proportion of all training places.

* The areas in which training is provided are stated in brackets. The predominant sector is placed first. CT indicates craft trades, TI denotes trade and industry.

Source: BIBB "Survey of newly concluded training contracts as of 30 September", Table 59 - 2016, as at 12.12.2016 (https://www.bibb.de/de/53972.php), own calculations 
Between 210 and 220 companies with relevant training place provision were surveyed on each of the nine occupations. The total sample size is 1,939 companies. The necessary sample was taken from the Federal Employment Agency company database and comprised a random selection of firms stratified for occupations and regions ${ }^{5}$. The purpose of stratification by regions was to avoid distortions by geographical area by ensuring that companies from the entire area of the Federal Republic of Germany were included in the sample for each occupation ${ }^{6}$. The statistical population for the sampling procedure was defined as being all small and medium-sized enterprises whose employees included at least one trainee in one of the occupations forming the object of consideration as of the cut-off date of 30 September 2015.

The issue as to whether a company had offered at least one training place in an occupation included in the sample in the training year 2015/2016 was clarified at the outset of the telephone interview by posing a screening question. The survey was only continued if this enquiry received an affirmative response. Alignment to the group of small and medium-sized enterprises was validated during the interview by obtaining information regarding number of employees. Firms with up to 49 employees are categorised as small companies. Those with between 50 and 249 employees are deemed to be medium-sized companies.

\subsection{Data}

Companies were asked by telephone to state which characteristics they had included in their written advertisements for training places offered in the 2015/2016 training year differentiated according to general conditions, requirements and incentives. The term "advertisement" was used as a collective designation for all forms of written or text-based announcements of training place provision. The purpose of limiting the investigation to text-related forms of notification was to ensure that training place characteristics were communicated by the company itself and had not been imparted as the result of an enquiry.

Inclusion of general conditions governing training and of requirements made of applicants was surveyed dichotomously (yes/no). Five characteristics were taken into consideration for each group (cf. Table 2). The collation of these characteristics was based on research works conducted into criteria frequently used by companies for the (pre) selection of training place applicants (cf. inter alia Kohlrausch \& Richter 2013, p. 7) and on findings relating to general conditions which are viewed by trainees as being important (inter alia Schank 2011, pp. 45-46).

In the case of incentives, which were compiled in alignment with existing studies on company training marketing (Eisele \& Ziegler 2013, p. 29; Eisele \& Ullrich 2014, p. 19) and via

5 We would like to take this opportunity to express our gratitude to the Federal Employment Agency for the support provided. 6 The German training market is characterised both by occupational disparities and regional imbalances (cf. inter alia Matthes et al. 2017). 
reference to research findings relating to expectations of young people vis-à-vis their company providing training (inter alia Schank 2011), a two-stage survey design was deployed. Firstly, companies were asked in respect of every incentive whether such an incentive was in place (yes/no). If a positive response was elicited, further dichotomous enquiry (yes/no) was made in order to identify whether the companies had also included the incentive in question in training place advertisements. For the purpose of the analyses undertaken in the present paper, the two dichotomous statements separately collected were each transferred to a categorial variable containing the three characteristics "incentive not in place", "incentive in place but not communicated" and "incentive in place and communicated" .

Table 2: Training place characteristics identified

\begin{tabular}{|c|c|}
\hline $\begin{array}{l}\text { Training place characteristics identified by a } \\
\text { singlestage process }\end{array}$ & $\begin{array}{l}\text { Training place characteristics identified by a } \\
\text { twostage process }\end{array}$ \\
\hline $\begin{array}{l}\text { General conditions } \\
\text { - Information regarding the training occupation, } \\
\text { - } \quad \text { Amo. duration and contents of training } \\
\text { - } \quad \text { Location of vocational school } \\
\text { - Information regarding the company providing } \\
\text { training, e.g. size and location } \\
\text { - Working times } \\
\text { Requirements } \\
\text { - Expected school education (qualification, marks) } \\
\text { - } \quad \text { Expected virtues, e.g. reliability, punctuality } \\
\text { - } \quad \text { Expected ability to work as part of a team } \\
\text { - Expected motivation and commitment }\end{array}$ & $\begin{array}{l}\text { Incentives } \\
\text { - Possibility of being offered permanent } \\
\text { - } \quad \text { Opployment after completion of training } \\
\text { - } \quad \text { Part-time training } \\
\text { - } \quad \text { Shortening of duration of training } \\
\text { - Periods of time spent abroad during training } \\
\text { - } \quad \text { Acquisition of additional qualifications } \\
\text { - Payment of necessary travel costs } \\
\text { - Payment of necessary accommodation costs } \\
\text { - } \quad \text { One-off financial incentives, e.g. funding of } \\
\text { - } \quad \text { Regular special payments, e.g. Christmas bonus }\end{array}$ \\
\hline
\end{tabular}

\subsection{Data analysis}

The first stage of the analysis involves a descriptive evaluation of which training place characteristics are more or less likely to be included in advertisements for training places offered. However, this descriptive consideration does not enable us to identify how companies combine the characteristics and whether these combinations follow certain patterns that are typical of groups of companies. Exploratory latent class analyses (LCA) are conducted in order to discover this.

An LCA is a multivariate analytical procedure. The primary objective of the exploratory type of LCA deployed here is to divide investigation units (in this case companies) into a priori unknown sub-groups (latent classes) (cf. Inter alia Geiser 2011, p. 235; Berlin, Williams \& 
Parra 2013, pp. 174-175). Groups are formed on the basis of the similarities and differences in the responses provided by the companies to questions relating to the training place characteristics communicated. One benefit of the LCA is that responses to both dichotomous and polytomous items can be included in the analyses at the same time.

The number of classes needed to map the data adequately is not a model parameter and must be determined indirectly via comparisons of models with different class numbers. Theoretical measurements from the group of information criteria (IC) are deployed for this purpose on the basis of Geiser (2011, pp. 260-271) and Geiser, Okun \& Grano (2014, pp. 10-11) - Akaike's information criteria (AIC), the Bayesian information criteria (BIC) and the sample size adjusted BIC (aBIC). The intention was to prefer the model with the lowest IC values, whereby the relevant literature particularly recommends the BIC (Geiser 2011, pp. 269-270).

The statistical test procedures used are the bootstrap likelihood ratio difference test (BLR test) and the Vuong-Lo-Mendell-Rubin Test (VLMR test). These enable a comparison to be undertaken between two models in which the class numbers differ by 1 . Significant test results indicate that the model with an additional class is a better fit for the data than the other model (Geiser 2011, pp. 260-271; Geiser, Okun \& Grano 2014, pp. 10-11). The BLR test is deemed to be the more robust of the two test procedures (Geiser 2011, pp. 265-269).

Further criteria included to evaluate the quality of the model are the mean class affiliation probabilities in their capacity as indicators of class homogeneity, the entropy as a global measure of reliability of the allocation of companies to classes, and the presence of boundary estimations. Boundary estimations often indicate that a model is invalid or exhibits too many classes (Geiser 2011, p. 270). Finally, the interpretability of the solution also has a part to play.

Alongside the patterns as such, the main point of interest here is whether correlations exist between the patterns and the occupation for which companies are seeking trainees. In order to explore this question, multi-group LCAs are performed for the whole sample once the number of classes has been determined. The grouping variable used is the occupational group (occupations with recruitment problems versus occupations without recruitment problems, cf. Section 3.1). Company size (small company versus medium-sized enterprise, cf. Section 3.1) is included as a further grouping variable. This accords due consideration to the fact that the segment of the economy which provides training in occupations with recruitment problems is more structured along the lines of small companies than the segment in which training takes pace in occupations without recruitment problems. Multi-group LCAs permit restrictions (equalisations of parameters between groups) to be used as a vehicle for checking whether the frequency with which patterns of training place characteristics communicated are exhibited vary with the occupational group, with company size or in terms of both variables. 
All analyses were conducted on the basis of the recommendations of Geiser (2011, pp. 235271), Berlin, Williams \& Parra (2013) and Muthén \& Muthén (2017, pp. 168-178) and using the software package Mplus Version 7.2.

\section{$4 \quad$ Results}

We will begin with a brief general look at which training place characteristics were communicated more frequently and more rarely by the companies surveyed in order to acquire potential applicants. A more detailed description of the findings of the LCAs on the patterns contained will then follow.

\subsection{Descriptive results for the training place characteristics communi- cated}

Table 3 shows the descriptive findings on the individual training place characteristics. These reveal that, as far as the general conditions are concerned, characteristics relating to the training occupations, such as the contents and duration of training, are most likely to be included in training place advertisements. Just over three quarters of the companies surveyed adopt this approach. This is understandable to the extent that companies increasingly complain that young people submit applications with very few clear occupational ideas (Association of German Chambers of Commerce and Industry 2016, pp. 14-15). Even information on the company itself (size, location) is significantly less likely to be imparted. Only just over half of companies include these details. The remaining general conditions form part of the training marketing of only between just over a fifth and just over a quarter of companies. 
Table 3: Proportion of companies which communicate the individual training place characteristics, in $\%$

\section{a) General conditions}

\begin{tabular}{|c|c|c|c|}
\hline a) General conditions & & & \\
\hline Characteristic & \multicolumn{2}{|c|}{ Not communicated } & Communicated \\
\hline $\begin{array}{r}\text { Information on the training } \\
\text { occupation }\end{array}$ & \multicolumn{2}{|c|}{23.8} & 76.2 \\
\hline $\begin{array}{r}\text { Information on the company } \\
\text { providing training }\end{array}$ & \multicolumn{2}{|l|}{45.8} & 54.2 \\
\hline Working times & \multicolumn{2}{|l|}{78.5} & 21.5 \\
\hline Amount of training allowance & 76.4 & & 23.6 \\
\hline Location of vocational school & 71.7 & & 28.3 \\
\hline \multicolumn{4}{|l|}{ b) Requirements } \\
\hline Characteristic & \multicolumn{2}{|c|}{ Not communicated } & Communicated \\
\hline Expected school education & 35.0 & \multicolumn{2}{|r|}{65.0} \\
\hline $\begin{array}{r}\text { Expected ability to work as part of a } \\
\text { team }\end{array}$ & 28.0 & & 72.0 \\
\hline Expected communication skills & \multicolumn{2}{|l|}{44.7} & 55.3 \\
\hline Expected motivation & \multicolumn{2}{|l|}{33.0} & 67.0 \\
\hline $\begin{array}{l}\text { Expected virtues } \\
\end{array}$ & 37.0 & & 63.0 \\
\hline \multicolumn{4}{|l|}{ c) Incentives } \\
\hline Characteristic & Not in place & $\begin{array}{l}\text { In place but not } \\
\text { communicated }\end{array}$ & $\begin{array}{l}\text { In place and } \\
\text { communicated }\end{array}$ \\
\hline $\begin{array}{r}\text { Possibility of subsequent permanent } \\
\text { employment }\end{array}$ & 11.2 & 56.6 & 32.2 \\
\hline Opportunities for advancement & 25.2 & 40.9 & 33.9 \\
\hline $\begin{array}{r}\text { Acquisition of additional } \\
\text { qualifications }\end{array}$ & 23.9 & 47.3 & 28.8 \\
\hline Periods of training spent abroad & 82.9 & 12.7 & 4.4 \\
\hline Regular special payments & 30.9 & 50.4 & 18.7 \\
\hline One-off financial incentives & 78.2 & 16.3 & 5.4 \\
\hline Payment of travel costs & 57.7 & 34.2 & 8.1 \\
\hline Payment of housing costs & 77.6 & 18.3 & 4.2 \\
\hline Shortening of duration of training & 23.4 & 57.0 & 19.6 \\
\hline $\begin{array}{ll}\text { Part-time training } \\
\end{array}$ & 87.6 & 9.2 & 3.2 \\
\hline
\end{tabular}

By way of contrast, requirements made of applicants are communicated by significantly higher proportions of the companies. They are particularly likely to formulate requirements regarding the ability of young people to work as part of a team, followed by motivational requirements. The requirements that are least likely to be addressed are those that relate to trainees' communication skills. Even so, just over one in two companies include these aspects in their training marketing.

As far as incentives are concerned, the first thing to be said is that there is a type of division between those which are found at large numbers of companies and those that are only available at comparatively few firms. Just under nine in ten companies, for example, offer the prospect of a permanent contract of employment upon conclusion of vocational education and training. However, only one in eight afford an opportunity to complete training on a 
part-time basis if necessary ${ }^{7}$. Irrespective of this, it is also revealed that only a relatively small proportion of companies with a certain incentive in place actually make use of this in their training marketing. Most companies fail to tap into the potential of offering incentives in order to gain kudos amongst potential applicants.

\subsection{Latent class analyses}

\subsubsection{Single group LCA}

The descriptive findings do not provide any response to the question as to whether the way in which companies combine (existing) training place characteristics within the scope of their training marketing exhibits certain patterns and, if this is the case, how many such patterns can be differentiated.

In order to investigate this issue, models containing between one and five latent classes were estimated for the entire sample across all 20 characteristics. The quality statistics for the five models are shown in Table 4. Replication of the best loglikelihood values proved possible for all models. This indicates clear solutions (Geiser 2011). The IC values AIC, BIC and aBIC become smaller from model to model without reaching a minimum. Although this finding implies a solution with more than five classes, the further parameters contradict this. The entropy, for example, achieves a lower value in the five-class solution than in the three and four-class solution and reaches its best value for the model with four classes. The result of the VLMR test also argues against the five-class solution and supports the four-class solution. By way of contrast, however, the BLR test indicates that the solution containing five classes is a model which is a better fit for the data. Notwithstanding this, boundary estimates have occurred both in the case of the four-class and the five-class model. Such estimates can be interpreted as indications of unreliable solutions and/or models with too many classes (Geiser 2011, p. 270). Finally, a consideration of the mean class affiliation probabilities shows that these each achieve satisfactory values of above 0.80 in all models but do not reach good values of over 0.90 . The latter figure only occurs in the case of the models with two and three classes.

\footnotetext{
7 Although part-time training is possible in all occupations, certain prerequisites need to be fulfilled (including parenting
} responsibilities or acting as a carer for a relative). 
Table 4 Model quality statistics for different latent class solutions

\begin{tabular}{|c|c|c|c|c|c|}
\hline Fit statistics & $\begin{array}{l}\text { 1-class } \\
\text { model }\end{array}$ & $\begin{array}{l}\text { 2-class } \\
\text { model }\end{array}$ & $\begin{array}{l}\text { 3-class } \\
\text { model }\end{array}$ & $\begin{array}{l}\text { 4-class } \\
\text { model }\end{array}$ & $\begin{array}{l}\text { 5-class } \\
\text { model } \\
\end{array}$ \\
\hline $\begin{array}{l}\text { Loglikelihood (number of } \\
\text { replications) }\end{array}$ & $\begin{array}{l}-27639.846 \\
(49 / 50)\end{array}$ & $\begin{array}{l}-26000.102 \\
(50 / 50)\end{array}$ & $\begin{array}{l}-25225.291 \\
(49 / 50)\end{array}$ & $\begin{array}{l}-24919.468 \\
(50 / 50)\end{array}$ & $\begin{array}{l}-24755.040 \\
(50 / 50)\end{array}$ \\
\hline AIC & 55339.691 & 52122.204 & 50634.582 & 50084.936 & 49818.080 \\
\hline BIC: & 55505.789 & 52461.969 & 51147.015 & 50770.037 & 50675.849 \\
\hline $\mathrm{aBIC}$ & 55411.478 & 52268.171 & 50854.727 & 50379.263 & 50186.587 \\
\hline Entropy & -- & 0.796 & 0.837 & 0.852 & 0.808 \\
\hline BLR test & -- & $\begin{array}{l}3279.487 \\
p<.0000 \\
\end{array}$ & $\begin{array}{l}1549.622 \\
p<.0000\end{array}$ & $\begin{array}{l}611.646 \\
p<.0000\end{array}$ & $\begin{array}{l}328.856 \\
P<.0000\end{array}$ \\
\hline VLMR test & -- & $\begin{array}{l}3265.572 \\
p<.0000\end{array}$ & $\begin{array}{l}1543.046 \\
p<.0000\end{array}$ & $\begin{array}{l}609.051 \\
p<.0000\end{array}$ & $\begin{array}{l}327.461 \\
P<.2969\end{array}$ \\
\hline Boundary estimates & No & No & No & Yes & Yes \\
\hline \multicolumn{6}{|c|}{ Mean class affiliation probabilities } \\
\hline 2-class model & c 1 & c 2 & & & \\
\hline c $1(39.1 \%)$ & 0.934 & 0.066 & & & \\
\hline c $2(60.1 \%)$ & 0.054 & 0.946 & & & \\
\hline 3-class model & c 1 & c 2 & c 3 & & \\
\hline c $1(29.4 \%)$ & 0.925 & 0.068 & 0.007 & & \\
\hline c $2(46.5 \%)$ & 0.047 & 0.922 & 0.031 & & \\
\hline c $3(24.1 \%)$ & 0.009 & 0.049 & 0.942 & & \\
\hline 4-class model & c 1 & c 2 & c 3 & c 4 & \\
\hline C1 (22.1\%) & 0.936 & 0.008 & 0.020 & 0.037 & \\
\hline C2 (26.5\%) & 0.004 & 0.929 & 0.007 & 0.060 & \\
\hline C3 (13.6\%) & 0.020 & 0.027 & 0.877 & 0.077 & \\
\hline C4 (37.8\%) & 0.026 & 0.047 & 0.018 & 0.909 & \\
\hline 5-class model & c 1 & c 2 & c 3 & c 4 & c 5 \\
\hline c $1(22.4 \%)$ & 0.837 & 0.074 & 0.070 & 0.001 & 0.017 \\
\hline c $2(25.5 \%)$ & 0.094 & 0.845 & 0.003 & 0.036 & 0.022 \\
\hline c $3(18.6 \%)$ & 0.091 & 0.003 & 0.894 & 0.011 & 0.001 \\
\hline c $4(12.6 \%)$ & 0.004 & 0.069 & 0.027 & 0.872 & 0.027 \\
\hline c 5 (20.8\%) & 0.017 & 0.023 & 0.002 & 0.017 & 0.941 \\
\hline
\end{tabular}

$\mathrm{N}=1.939$

An analysis of the patterns resulting for the three and four-class solution ultimately showed that the patterns of two latent classes in the four-class solution were very similar in terms of their fundamental structure (cf. Annex 1), whereas the patterns of all latent classes vary more significantly in the case of the three-class solution (cf. Fig. 1 to 3).

In conjunction with the criterion of parsimony, the results thus suggest that the threeclass model should be accepted as a clear and interpretable solution which is suitable for the data. In accordance with their patterns, the classes of this solution can be interpreted as "aggressive training marketing" (class 1), "requirements-oriented training marketing" (class 2) and "basic training marketing" (class 3 ). 
In specific terms, training marketing in aggressive class 1 is characterised by a wide-ranging communication pattern (cf. Fig. 1). Companies that belong to this class are more likely to use all training place characteristics as an object of training marketing than companies in the two other classes. One prominent aspect is that the marketing potential offered by existing incentives is frequently exploited.

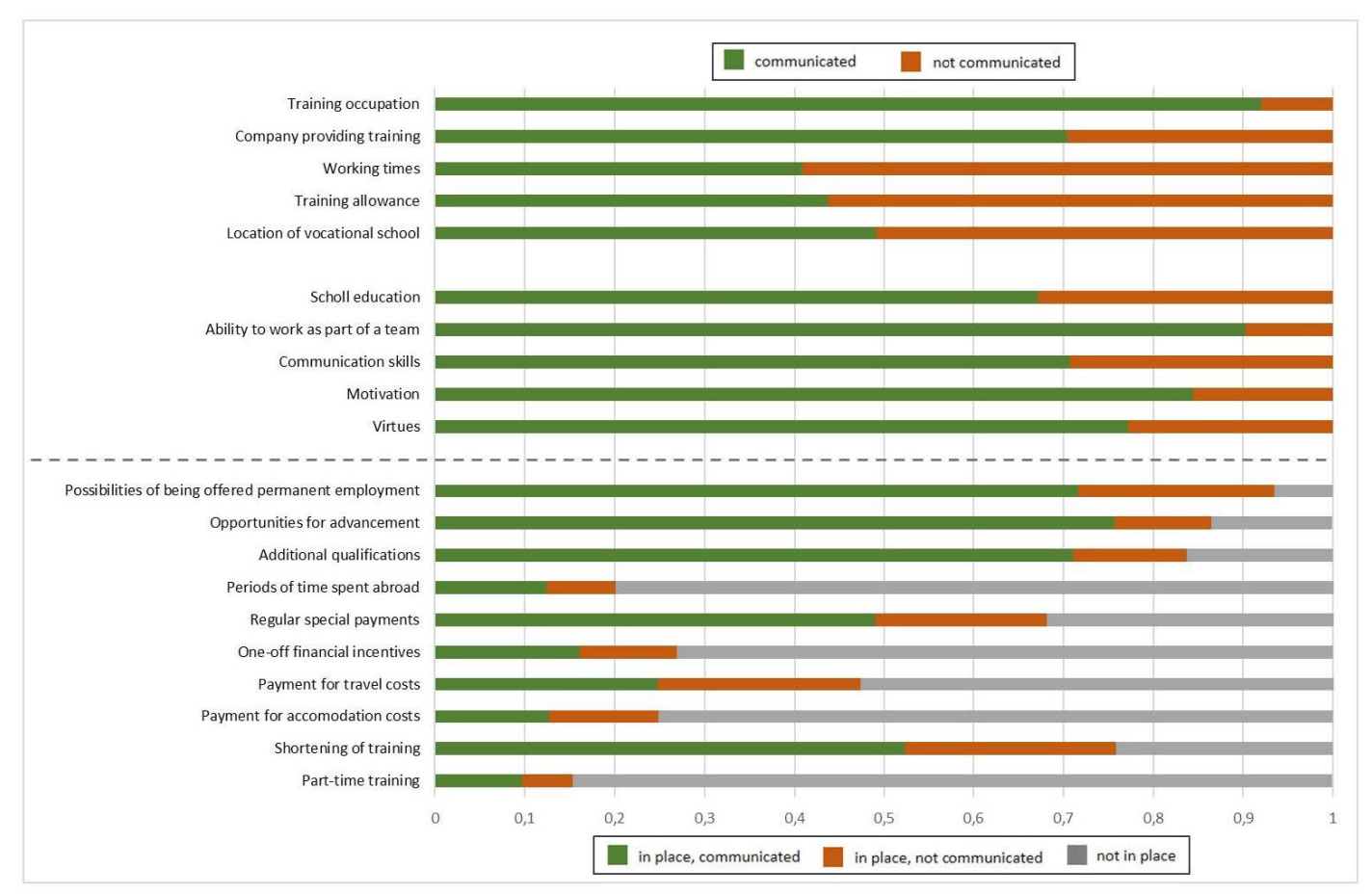

Fig. 1: Latent class 1 - aggressive training marketing

By way of contrast, existing incentives are highly likely not to be communicated in the case of requirements-oriented training marketing in class 2 and basic training marketing in class 3 (cf. Fig. 2 and 3 ) even if the probability that such incentives are in place is similar to in class 1. Instead of this, companies in class 2 (which accounts for $46.5 \%$ of firms and constitutes the largest class) are highly likely to address the requirements that they make of training place applicants. Such an approach tends to be unlikely in the case of companies which pursue basic training place marketing. In overall terms, it is not very probable that companies falling within class 3 will communicate training place characteristics. The likelihood that they will do so is only somewhat higher with regard to information on the company providing training and prior school learning of applicants. 


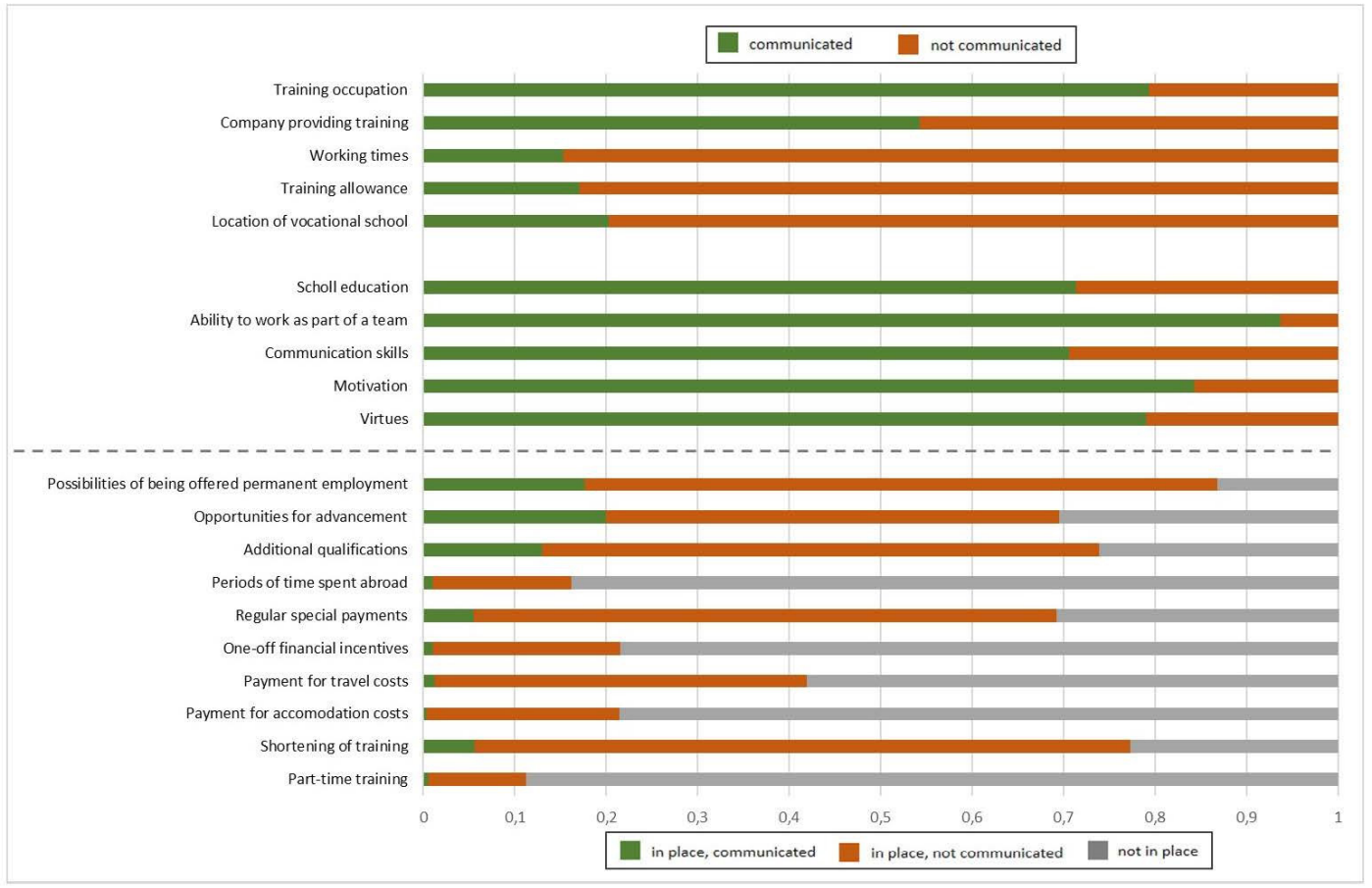

Fig. 2: Latent class 2 - requirements-oriented training marketing

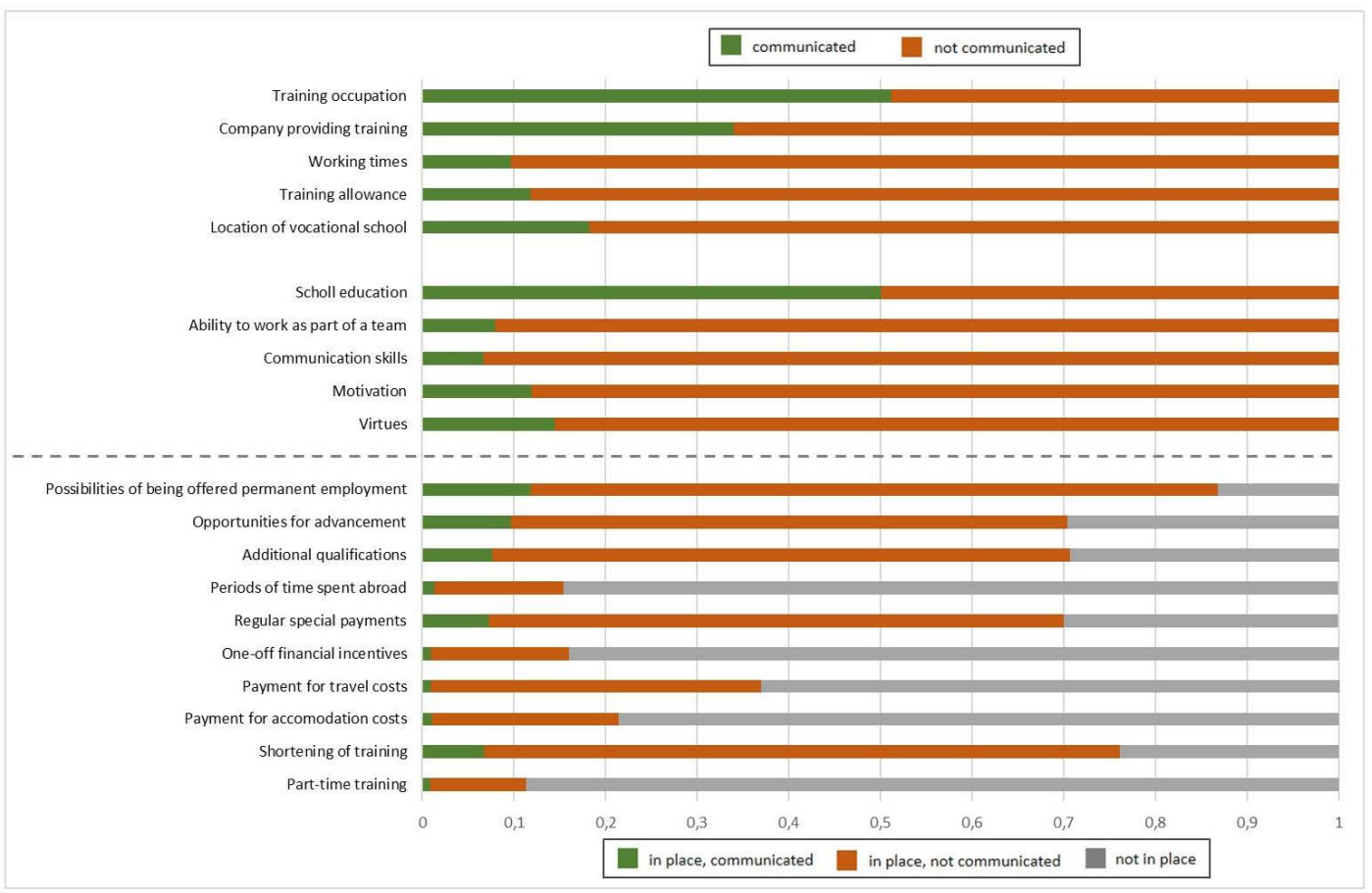

Fig. 3: Latent class 3 - basic training marketing 


\subsubsection{Multi-group LCAs}

Multi-group LCAs were subsequently performed in order to undertake a detailed analysis of the three-class solution identified. In specific terms, the object of investigation was to discover whether the three patterns of company training marketing occur in a structurally identical way but with varying frequency at companies offering training places in occupations with or without recruitment problems and/or at companies of different sizes. In order to test this, various models were estimated which allow the class size to be varied between the four occupational groups (2 types of occupation [with/without recruitment problems] x 2 company sizes [small company/medium-sized enterprise]) but which also enable equality restrictions to be used to keep the marketing patterns constant for different company groups. Model 1, which permits structurally varying patterns of training place characteristics communicated between all four company groups, constitutes an exception in this regard. Model 2 specifies structurally equal patterns for companies in both size classes but not for companies of both occupational types. This model accordingly investigates whether frequency of communication patterns varies with company size. By the same token, model 3 keeps constant patterns for companies of both occupational types but not for companies in both size classes. This investigates whether type of occupation is associated with varying frequencies of the patterns. Finally, model 4 defines structurally identical patterns for all four company groups. This model accordingly checks whether frequency of the individual patterns varies by company size and type of occupation, i.e. whether the occurrence of the individual patterns is more likely for certain of the four company groups than for others.

The statistics on model quality in Table 5 show that a different model appears to be the best fit for the data depending on the parameter observed. The only exception in this regard is model 3, which does not reach the best value for any of the parameters. Model 1 exhibits both the smallest AIC and the best global measure for reliable classification (entropy). In the case of model 2, the BIC adjusted for the sample size adopts the smallest value. However, boundary estimations occur in respect of both models. No boundary estimations are contained in model 4, which also has the lowest BIC value. Because BIC is considered to be a particularly valid measure of model quality (inter alia Geiser 2011, pp. 269-270) and boundary estimations frequently indicate invalid solutions, we would appear to be justified in viewing model 4 as the best fit for the data structure, especially as observation of the respective patterns has produced very similar structures for all four models. The results of the analyses also suggest that the three training marketing patterns occur at companies with differing levels of frequency depending on whether the firm in question is a small or medium-sized company or is seeking trainees for an occupation which has or does not have recruitment problems. 
Table 5 Fit statistics for different multi-group models with three latent classes

\begin{tabular}{|l|c|c|c|c|}
\hline & Model 1 & Model 2 & Model 3 & Model 4 \\
\hline & $\begin{array}{c}\text { Varying class profiles } \\
\text { across all four } \\
\text { company groups }\end{array}$ & $\begin{array}{c}\text { Same class } \\
\text { profiles for } \\
\text { company size }\end{array}$ & $\begin{array}{c}\text { Same class } \\
\text { profiles for } \\
\text { training } \\
\text { occupations }\end{array}$ & $\begin{array}{c}\text { Same class profiles } \\
\text { across all four } \\
\text { company groups }\end{array}$ \\
\hline $\begin{array}{l}\text { Loglikelihood } \\
\text { (number of } \\
\text { replications) }\end{array}$ & $\begin{array}{c}-27136.256 \\
(35 / 50)\end{array}$ & $\begin{array}{c}-27350.963 \\
(50 / 50)\end{array}$ & $\begin{array}{c}-27387.878 \\
(50 / 50)\end{array}$ & $\begin{array}{c}-27623.524 \\
(50 / 50)\end{array}$ \\
\hline AIC & $\mathbf{5 5 0 1 0 . 5 1 1}$ & 55083.925 & 55157.756 & 55449.047 \\
\hline BIC: & 57076.955 & 56147.789 & 56221.612 & $\mathbf{5 6 0 1 1 . 6 1 0}$ \\
\hline aBIC & 55898.279 & $\mathbf{5 5 5 4 0 . 9 7 0}$ & 55614.801 & 55690.731 \\
\hline Entropy & $\mathbf{0 . 9 4 3}$ & 0.934 & 0.934 & 0.928 \\
\hline $\begin{array}{l}\text { Boundary } \\
\text { estimations }\end{array}$ & Yes & Yes & Yes & No \\
\hline
\end{tabular}

Table 6 shows these frequencies. They indicate that aggressive training marketing is more likely to occur at both small and medium-sized enterprises if they are seeking trainees for occupations with recruitment problems than if they are attempting to find trainees for occupations without such difficulties. By the same token, small and medium-sized companies with training provision in occupations with recruitment problems are less likely to exhibit training marketing aligned to the requirements of applicants than firms offering training in occupations without recruitment difficulties, although this is significantly more clearly manifested amongst small companies than medium-sized firms. Nevertheless, the class with requirements-oriented marketing constitutes the largest class for all four company groups.

Another interesting aspect to be revealed, however, is that small companies offering training places in occupations with recruitment problems are more likely than small companies with training provision in occupations without recruitment problems to display basic marketing. The opposite applies in the case of medium-sized enterprises. Companies offering training places in occupations without recruitment problems are more likely to exhibit this pattern than companies with training places in occupations with recruitment problems. 
Table 6 Latent class proportions for model 4 of the multi-group latent class analysis

\begin{tabular}{|c|c|c|c|c|}
\hline & Small cc & anies & Medium-size & tterprises \\
\hline & $\begin{array}{r}\text { Training plac } \\
\text { occu }\end{array}$ & $\begin{array}{l}\text { ovision for } \\
\text { on }\end{array}$ & $\begin{array}{r}\text { Training plac } \\
\text { occu }\end{array}$ & $\begin{array}{l}\text { ovision for } \\
\text { n }\end{array}$ \\
\hline Latent class & $\begin{array}{l}\text { with recruitment } \\
\text { problems }\end{array}$ & $\begin{array}{l}\text { without } \\
\text { recruitment } \\
\text { problems }\end{array}$ & $\begin{array}{l}\text { with recruitment } \\
\text { problems }\end{array}$ & $\begin{array}{l}\text { without } \\
\text { recruitment } \\
\text { problems }\end{array}$ \\
\hline $\begin{array}{l}\text { Class } 1 \\
\text { Aggressive training } \\
\text { marketing }\end{array}$ & $33.3 \%$ & $22.6 \%$ & $36.7 \%$ & $26.6 \%$ \\
\hline $\begin{array}{l}\text { Class } 2 \\
\text { Requirements-oriented } \\
\text { training marketing }\end{array}$ & $39.0 \%$ & $55.5 \%$ & $47.7 \%$ & $50.3 \%$ \\
\hline $\begin{array}{l}\text { Class } 3 \\
\text { Basic training marketing }\end{array}$ & $27.7 \%$ & $22.8 \%$ & $15.5 \%$ & $22.8 \%$ \\
\hline
\end{tabular}

\section{Conclusion}

One of the main pathways via which German companies secure their skilled worker requirements is by offering their own training, but increasing recruitment problems are now calling this approach into question. This has raised the question of how companies respond to these problems. Particular attention was directed towards the extent to which companies amend or lower the criteria which they use to select training place applicants (inter alia Ebbinghaus \& Gerhards 2013; Dummert, Frei \& Leber 2014, pp. 5-6). However, companies do not have the ability to make such a selection until they have succeeded in using their training marketing to motivate young people to make an application. Because a growing number of companies is no longer achieving this objective (Association of German Chambers of Commerce and Industry 2017, p. 11), issues relating to company training marketing are gradually meeting with a higher degree of research interest. Within this context, the present paper has investigated which characteristics of training places are communicated in advertisements by small and medium-sized enterprises.

The analyses conducted show that companies adopt highly differing approaches in this regard. This is made clear by dint of the fact that it proved possible to identify three patterns of training place characteristics communicated, each of which displays specific main focuses. As well as concentrating on general conditions and the requirements for training, the "aggressive" pattern mainly emphasises the incentives offered by the "training place product". Requirements-oriented training marketing largely avoids any attempt to exploit the potential of existing incentives by primarily addressing the requirements made of future trainees. In overall terms, basic training marketing targets only a very few fundamental training place characteristics. More detailed analyses also enabled us to find indications that both the type of training occupation in which companies are seeking trainees and company size play a part 
in the marketing strategy exhibited by the firms. Aggressive training marketing is conspicuously likely to be conducted by companies offering training in occupations with recruitment problems. It is, however, also noticeable that a high proportion of small companies with training provision in occupations with recruitment problems takes the opposite approach by adopting basic training marketing, although this pattern is comparatively rare amongst medium-sized enterprises providing training in the same occupational segment. Firstly, these findings lead to the conclusion that companies tend to use the portfolio of training place characteristics communicated in a similar way to the routes which they adopt to communicate training place provision (Gerhards \& Ebbinghaus 2014; Association of German Chambers of Commerce and Industry 2017, pp. 13-14), i.e. to react to recruitment problems that already exist rather than as a means of taking preventative action to counter such difficulties. Secondly, the findings suggest that small companies in particular seem to experience limitations with regard to adapting training marketing to altered circumstances on the training market. This is probably due to the fact that, in contrast to medium-sized enterprises and larger companies, small firms do not in many cases have the necessary experience and / or resources available to develop training marketing which is aligned to the market and to the exploitation of areas of potential offered by existing incentives. In this case, approaches should be considered to help small businesses overcome these limitations. One way could be support offers from chambers and associations that go beyond existing image campaigns, which are usually related to certain occupations or sectors (e.g. the campaign of the bakery trade: https://www.back-dir-deine-zukunft.de/), by addressing the needs and even more so the potentials of individual companies. Such support services could also help small enterprises, but also training companies as a whole, to become more proactive than in the past in order to cope with changes in the training market.

The circumstance that small companies are conspicuously likely only to provide basic information about training characteristics may, however, also indicate that these firms (still) only make limited overall use of the written and text-based advertisements forming the present object of investigation for the purpose of acquisition of training place applicants and instead tend to attempt to fill training places via personal contacts and relationships. Although initial findings which point in this direction have been arrived at (Gerhards \& Ebbinghaus 2014, pp. 12-14; Ebbinghaus, Bahl, Gei \& Flemming 2017, pp. 14-17), further research work will be needed to back these results up.

More research should also be conducted to address the question of the effectiveness of different strategies for the communication of general conditions, requirements and in particular incentives for the "training place product" for the purpose of acquiring applicants and trainees. Such research activities could go beyond the mere obtaining of more academic research findings and make a contribution towards the scrutiny and consolidation of the re- 
commendations on the structuring of company training marketing that are contained within the diverse guidance literature.

Last but not least, further research work on the patterns of company training marketing identified in the present paper would be desirable. Although the three-class solution may be assumed to be a justified approach, there are a number of aspects which certainly indicate the suitability of a solution which contains more classes. Evidence was also found for the assumption that frequency of the marketing patterns varies in line with company size and occupational group. Notwithstanding this, consolidation of this assumption vis-à-vis other assumptions, particularly with regard to variation of frequency purely in line with company size, proved to be somewhat weak. For this reason, further studies into the marketing behaviour of companies should be carried out which involve either a larger sample size or else address a differently constituted number of dual training occupations. Especially in the case of multi-group analyses, sample sizes in the individual sub-groups rapidly become low. To a certain extent, this may exert a negative impact on the reliability of the results or the homogeneity of the sub-groups. At the same time, higher sample sizes and numbers of occupations could shed greater light on the occupational-specific nature of company training marketing and also allow the investigation of further factors influencing such marketing which have not been taken into account here.

A deeper understanding of the conditions, logics and successes of training marketing is important not only with regard to the German training and skilled labour market. In many European and non-European countries, high youth unemployment and a shortage of skilled workers with the qualifications required by the economy have led to a stronger emphasis on the implementation or expansion of in-company training concepts (e. g. Euler 2013, p. 11; Cedefop 2018). Such efforts can be found, for example, in France, the United Kingdom, Norway and the Netherlands (Cedefop 2018). In many countries, the lower attractiveness of vocational education and training compared to higher education poses a major challenge (ibidem). To cope with this, image campaigns were launched, among other things, to demonstrate the advantages of vocational training in order to attract both companies and young people to participate. For example, last year the UK Department of Apprenticeship

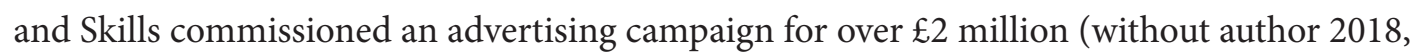
S. 7). .The fact that such measures have so far only led to limited success may also have something to do with the fact that the training places offered by companies and other practical players are still perceived as not being very attractive. This suggests that marketing for the VET system must be accompanied by marketing for individual training places. It is true that the study presented here does not allow any conclusions to be drawn as to whether companies will be more successful in filling training places as a result of strong marketing. However, there are indications from practical experience that good marketing can make it possible to make in-company training places sought after by young people, even if the VET system is less 
well regarded in society as a whole. Even if these indicators concern training places offered by companies with a high reputation ${ }^{8}$, they suggest that smaller companies - and thus the vocational training sector as a whole - will also benefit from good marketing strategies.

\section{References}

Allen, D. G., Van Scotter, J. R., \& Otondo, R. F. (2000). Recruitment communication media: impact on prehire outcomes. Personnel Psychology 57 (1), pp. 143-171.

Backhaus, K., Tikoo, S. (2004). Conceptualizing and researching employer branding. Career Development International 9(5), pp. 501-517.

Beck, C., \& Dietl, S. F. (Eds.). (2014). Ausbildungsmarketing 2.0. Die Fachkräfte von morgen ansprechen, gewinnen und binden [Training marketing 2.0. Appealing to, acquiring and securing the loyalty of the skilled workers of the future]. Cologne, Germany: Luchterhand.

Berlin, K. S., Williams, N. A., \& Parra, G. R. (2013). An Introduction to Latent Variable Mixture Modeling (Part 1): Overview and Cross-Sectional Latent Class and Latent Profile Analysis. Journal of Pediatric Psychology, 39(2), 174-187.

Berthon, P., Ewing, M, \& Hah, L. L. (2005). Captivating company. Dimensions of attractiveness in employer branding. International Journal of Advertising, 24(2), 151-172.

Böckenholt, I., \& Homburg, C. (1990). Ansehen, Karriere oder Sicherheit? Entscheidungskriterien bei der Stellenwahl von Führungsnachwuchs in Großunternehmen [Esteem, career or security? Decision-making criteria in job choice by young managers at major companies]. Zeitschrift für Betriebswirtschaft [Journal of Business Administration], 60(11), 1159-1181.

B orn, M. P., \& Taris, T. W. (2010). The impact oft he wording of employment advertisements on students inclination to apply for a job. Journal of Social Psychology, 150(5), 485-502.

Brast, C., Holtgrave, M., \& Flindt, I. (2017). Erfolgsfaktoren des Employer Branding - eine empirische Analyse [Success factors in employer branding - an empirical analysis]. PERSONAL quarterly, 69(2), 36-44.

Breaugh, J. A., \& Starke, M. (2000). Research an employee recruitment: so many studies, so many remaining questions. Journal of Management, 26(3), 405-434.

B oxall, P. (1998). Achieving competitive advantage through human ressource strateg y: towards a theory of industry dynamics. Human Ressource Management Review, 8(3), 265-288.

Cedefop (2018). The changing nature and role of vocational education and training in Europe. Volume 3: the responsiveness of European VET systems to external change (1995-2015). Luxembourg, Luxembourg: Publications Office oft he European Union.

Collins, C. J., \& Stevens, C. K. (2002). The relationship between early recruitment-related activities and the application decisions of new labor-market entrants: A brand equity approach to recruitment.

Journal of Applied Psychology, 87(6), 1121-1133.

8 E. g. Rolls Royce: https://careers.rolls-royce.com/united-kingdom/students-and-graduates/apprenticeships-and-school-leavers; Jaguar Land Rover: https://www.jaguarlandrovercareers.com/key/jlr-apprenticeships.html; Techtonic Group (Magyar 2018). 
Deutscher Industrie- und Handelskammertag (DIHK) [Association of German Chambers of Commerce and Industry] (2017). DIHK-Ausbildungsumfrage 2017 [DIHK Training Survey 2017] [brochure]. Berlin, Germany:BIBB.

Deutscher Industrie- und Handelskammertag (DIHK) [Association of German Chambers of Commerce and Industry] (2016). DIHK-Ausbildungsumfrage 2016 [DIHK Training Survey 2017] [brochure]. Berlin, Germany: BIBB.

Dummert, S. Frei, M., \& Leber, U. (2014). Betriebe und Bewerber finden schwerer zusammen, dafür sind Übernahmen häufiger denn je [Companies and applicants find it harder to find each other, but takeovers are more frequent than ever]. IAB-Kurzbericht 20/2014.

Ebbinghaus, M., Bahl, A., Flemming, S., Gei, J., \& Hucker, T. (2013). Rekrutierung von Auszubildenden - Betriebliches Rekrutierungsverhalten im Kontext des demografischen Wandels. Erste Ergebnisse aus Betriebsinterviews [Recruitment of trainees - company recruitment behaviour in the context of demographic change. Initial results from company interviews]. Retrieved from the Federal Institute for Vocational Education and Training website https:/www.bibb.de/dokumente/ pdf/a21_22-0067_Rekrutierung_vonAuszubildenden_Berichte_aus_den_Interviews_201307.pdf

Ebbinghaus, M., \& Gerhards, C. (2013). Betriebliche Flexibilität beim Qualifikationsprofil von Ausbildungsanfängern bei Besetzungsproblemen von Ausbildungsstellen [Company flexibility in the skills profile of training entrants in the case of recruitment problems for training places]. Zeitschrift für Nachwuchswissenschaftler [Young Academic Researchers' Journal] 8(1), 5-20.

Eberhard, V., Scholz, S., \& Ulrich, J. G. (2009). Image als Berufswahlkriterium [Image as a career choice criterion]. Berufsbildung in Wissenschaft und Praxis [Vocational Training in Research and Practice] 38(3), 9-13.

Edwards, M. R. (2010). An integrative review of employer branding ans OB theory. Personnel Review, 39(1), 5-23.

Eisele, D. S.; Ziegler, C. (2013). Azubi-Recruitingtrends 2013. Management Summary [Trainee recruitment trends 2014. Management Summary]. Solingen, Germany: u-form

Esser, H. (1999). Soziologie. Spezielle Grundlagen: Situationslogik und Handeln [Sociology. Special principles. Situational logic and action]. Frankfurt am Main, Germany: Campus

Euler, D. (2013). Das duale System in Deutschland - Vorbild für einen Transfer ins Ausland? [The dual system in Germany - a model for a transfer abroad?] Bielefeld, Germany: Bertelsmann Stiftung.

Farmer, H., Rotella, S., Anderson, C., \& Wardrope, J. (1998). Gender differences in science, math, and technology careers: Prestige level and Holland interest type. Journal of Vocational Behaviour, 53, 73-96.

Feldman, D. C., Bearden, W. O., \& Hardesty, D. M. (2006). Varying the content of job advertisements: the effects of message specificity. Journal of Advertising, 35(1), 123-141.

Feldmann, M., \& Arnold, H. J. (1978). Position choice: comparing the Importance of Organizational and Job Factors. Journal of Applied Psychology, 63(3), 706-710.

Freimuth, J. (1989). Personalimage - Das Erscheinungsbild als Arbeitgeber [Human resources image - impression given as an employer]. Personal, 41(2), 42-47.

Gei, J., \& Eberhard, V. (2017). Die Bedeutung des Betriebs bei der Suche nach einer Ausbildungsstelle - Ergebnisse der BA/BIBB-Bewerberbefragung 2016 [Significance of the company in the search for a training place - results of the 2016 BA/BIBB Applicant Survey]. In Bundesinstitut für Berufsbildung [Federal Institute for Vocational Education and Training] (Ed.) Datenreport zum Berufsbildungsbericht 2017 [Data Report to accompany the 2017 Report on Vocational Education 
and Training] (pp. 260-265) Bonn, Germany: Bundesinstitut für Berufsbildung [Federal Institute for Vocational Education and Training].

Geiser, C. (2011). Datenanalyse mit Mplus [Data analysis using Mplus]. Wiesbaden, Germany: Verlag für Sozialwissenschaften. 2nd revised edition.

Geiser, C., Okun, M. A., \& Grano, C. (2014). Who is motivated to volunteer? A latent profile analysis linking volunteer motivation to frequency of volunteering. Psychological Test and Assessment Modeling, 56(1), 3-24.

Gerhards, C., \& Ebbinghaus, M. (2014). Betriebe auf der Suche nach Ausbildungsplatzbewerberinnen und -bewerbern: Instrumente und Strategien [Companies seeking training place applicants - instruments and strategies]. Results from the 2013 BIBB Training Panel BIBB Report 3/2014 Retrieved from https://www.bibb.de/veroeffentlichungen/de/publication/show/7458

Gessler, M. (2017). The Lack of Collaboration Between Companies and Schools in the German Dual Apprenticeship System: Historical Background and Recent Data. International Journal for Research in Vocational Education and Training (IJRVET), 4(2), 164-195.

Gottfredson, L. (2002). Gottfredson's theory of circumscription, compromise and self-creation. In D. Brown (Ed.). Career choice and development (pp. 85-148). 4th Edition. San Francisco, California: Jossey-Brass.

Herkner, V. (2013). Berufspädagogische Aspekte zu einem Recht auf berufliche Ausbildung - Anspruch, Realität und Umsetzung [Vocational pedagogy aspects of a right to vocational education and training - aspiration, reality and implementation]. Berufs- und Wirtschaftspädagogik online [Vocational and Business Education online] Issue 25, 1-27. Retrieved from http://www.bwpat. de/ausgabe25/herkner_bwpat25.pdf

Holland, J. L. (1966). The psychology of vocational choice. Waltham, Massachusetts: Blaisdell.

Howe, N.; Strauss, W. (1991). Generations: The History of America's Future, 1584 to 2069. New York, USA: William Morrow \& Company.

Hurrelmann, K. (2016). Was erwarten Jugendliche vom Berufsleben? Die Bedürfnisse und Wünsche der Generationen $Y$ und $Z$ [What do young people expect from work? Needs and wishes of Generation Y and Z]. Berlin, Germany. Retrieved from https://www.bildungsketten.de/_media/BKKonferenz_Vortrag_Hurrelmann.pdf

Jansen, A., Pfeifer, H., Schönfeld, G., \& Wenzelmann, F. (2015). Ausbildung in Deutschland weiterhin investitionsorientiert - Ergebnisse der BIBB-Kosten-Nutzen-Erhebung 2012/13 [Apprenticeship training in Germany remains investment focused - results of the 2012/13 BIBB Cost-Benefit Survey]. BIBB Report 1/2015: Retrieved from https://www.bibb.de/de/25852.php

Kaiumov, A. T.; Kanikov, F. K., \& Iskhakova, N. R. (2014). What young students in a major industrial city think about the prestige of professions. Russian Education ans Society 56(7), 40-57.

Kluemper, D. h., Mitra, A., \& Wang, S. (2016). Social media use in HRM. In M. R. Buckley, J. R B. Halbesleben, A. R. Wheeler (Ed.). Research in personnel and human ressource management (pp. 153-207). Bingley, UK: Emerald Group Publishing Limited.

Kohlrausch, B.; \& Richter, M. (2013). Betriebe als Gatekeeper. Rekrutierungsprozesse auf dem Ausbildungsmarkt [Companies as gatekeepers. Recruitment processes on the training market]. Mitteilungen aus dem SOFI, [Sociological Research Institute Reports] 7(3), 6-9. 
Lieber, B. (1995). Personalimage. Explorative Studie zum Image und zur Attraktivität von Unternehmen als Arbeitgeber [Human resources image. Exploratory study on the image and attractiveness of companies as employees]. Munich, Germany: Hampp.

Magyar, C. (2018). In search of apprentices. Techtonic Group recruits and trains non-traditional candidates to fill its IT pipeline. Talent Development, December 2017, 32-36.

Mannheim, K. (1952). The Problem of Generations. In P. Kecskemeti (Ed.). Essays on the Sociology of Knowledge: Collected Works, Volume 5 (pp. 276-322). New York, USA: Routledge.

Matthes, S., Ulrich, J. G., Flemming, S., Granath, R.-O. (2017). Angebot und Nachfrage mit leichtem Plus, jedoch erneut mehr unbesetzte Plätze. Die Entwicklung des Ausbildungsmarktes im Jahr 2017 [Supply and demand slightly up, but more unfilled places once again. Development of the training market in the year 2017]. Retrieved from the Federal Institute for Vocational Education and Training website https://www.bibb.de/ausbildungsmarkt2017

Mencken, F. C., \& Winfield, I. (1998). In search of the 'right stuff': the advantages and disadvantages of informal and formal recruiting practices in external labor markets. American Journal of Economics \& Sociology, 58(2), 135-153.

Merrilees, W. J. (1983). Alternative models of apprentice recruitment: With special reference to the British engineering industry. Applied Economics 15(1), 1-21.

Mosley, R. (2015). Corporate communications. CEOs need to pay attention to employer branding. Harvard Business Review, May 11, 2015, Retrieved from https://hbr.org/2015/05/ceos-need-topay-attention-to-employer-branding

Muthén, L. K., \& Muthén, B. O. (2017). Mplus User’s Guide. Version 8. Los Angeles, California: Muthén \& Muthén.

Niederlat, M. (2005). Bestimmungsgründe des betrieblichen Ausbildungsverhaltens in Deutschland [Reasons companies participate in the dual vocational education and training in Germany]. Nürnberg, Germany: Universität Erlangen-Nürnberg 2005.

Rojewski, J. W. (2005). Occupational aspirations: Constructs, meaning, and application. In S. D. Brown \& R. W. Lent (Eds.), Career development and counselling: Putting theory and research to work (pp. 131-154). Hoboken, New Jersey: John Wiley.

Rojewski, J. W., \& Kim, H. (2003). Career choice patterns and behaviour of work-bound youth during early adolescence. Journal of Career Development 30, 89-108.

Schank, C. (2011). Der Einfluss der Betriebsgröße bei der Ausbildungsplatzsuche [The influence of company size on the search for a training place]. Berufsbildung in Wissenschaft und Praxis [Vocational Training in Research and Practice] 40(3), 44-47.

Smith, T. W., \& Son, J. (2014). Measuring Occupational Prestige on the 2012 General Social Survey. NORC at the University of Chicago. GSS Methodological Report No. 122. Retrieved from http:// gss.norc.org/Documents/reports/methodological-reports/MR122\%20Occupational\%20Prestige. pdf

Steinritz, G., Kayser, H., Ziegler, B. (2012). Erfassung des beruflichen Aspirationsfeldes Jugendlicher IbeA, ein Diagnoseinstrument für Berufsorientierung und Forschung [Identification of the field of occupational aspiration of young people - IneA, a diagnostic instrument for vocational orientation and research]. Berufs- und Wirtschaftspädagogik online [Vocational and Business Education online] 22, 1-18. Retrieved from http://www.bwpat.de/ausgabe22/steinritz_etal_bwpat22.pdf 
Stillman, D., \& Stilman J. (2017). Generation Z @ work: How the next generation is transforming the workplace. New York, USA: HarperCollins

Troltsch, K. (2017a). Betriebliche Ausbildungsbeteiligung - Ergebnisse aus dem BIBB-Qualifizierungspanel [Company training participation - results from the BIBB Training Panel]. In Bundesinstitut für Berufsbildung [Federal Institute for Vocational Education and Training] (Ed.) Datenreport zum Berufsbildungsbericht 2017 [Data Report to accompany the 2017 Report on Vocational Education and Training] (pp. 228-236) Bonn, Germany, Bundesinstitut für Berufsbildung [Federal Institute for Vocational Education and Training]

Troltsch, K. (2017b). Betriebliche Ausbildungsbeteiligung - Ergebnisse der Beschäftigungsstatistik zur Ausbildungsbeteiligung [Company participation in training - results of the employment statistics on participation in training]. In Bundesinstitut für Berufsbildung [Federal Institute for Vocational Education and Training] (Ed.) Datenreport zum Berufsbildungsbericht 2017 [Data Report to accompany the 2017 Report on Vocational Education and Training] (pp. 214-226) Bonn, Germany, Bundesinstitut für Berufsbildung [Federal Institute for Vocational Education and Training]

Van Hoye, G. (2012). Recruitment sources and organizational attraction: a field study of Belgian nurses. European Journal of Work and Organizational Psychology, 21(3), 376-391.

Van Hoye, G., \& Lievens, F. (2009). Tapping the grapevine: A closer look at word-of-mouth as a recruitment source. Journal of Applied Psychology, 94(2), 341-352.

Van Hoye, G., \& Lievens, F. (2007). Investigating web-based recruitment sources: Employee testimonial versus word-of-mouth. International Journal of Selection and Assessment, 15(4), 372-382.

Vroom, V. (1964). Work and Motivation. New York City, New York: Wiley

Wille, L., Derous, E. (2018). When job ads turn you down: how requirements in job ads may stop instead of attract highly qualified women. Sex Roles, 78(7/8), 464-475.

Without Author (2018). Government spending millions on marketing campaign to rescue failed apprenticeships policy. Educational Journal, 360, 7.

Wodarz, N. (2018). Social media: new strategy for talent management: social media ist rising to the top as an effective recruiting strategy. School Business Affairs, 84(4), 12-15.

\section{Data systems}

Database BIBB survey as of 30 September (BIBB "Survey of newly concluded training contracts as of 30 September”. https://www.bibb.de/de/39323.php 


\section{Appendix}

Patterns of the four-class solution

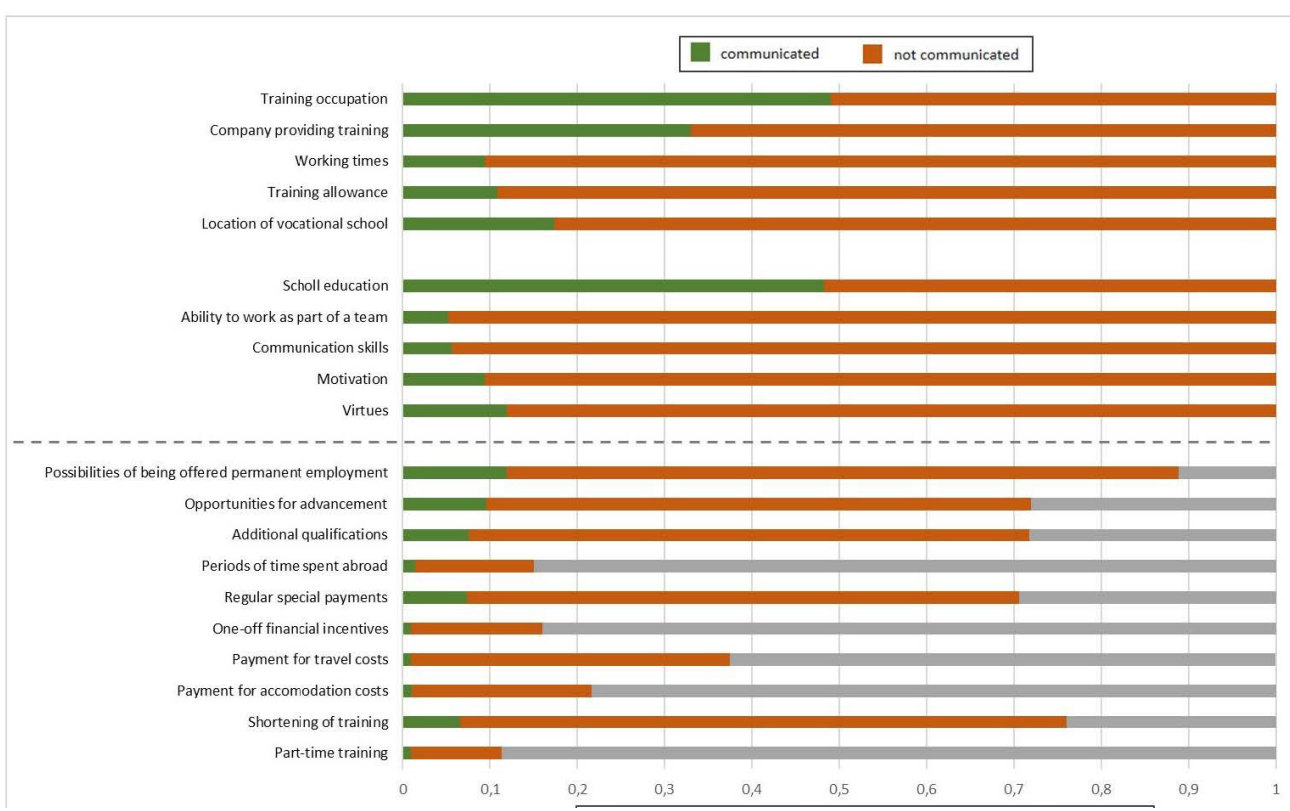

Fig. 1-A: Latent class 1

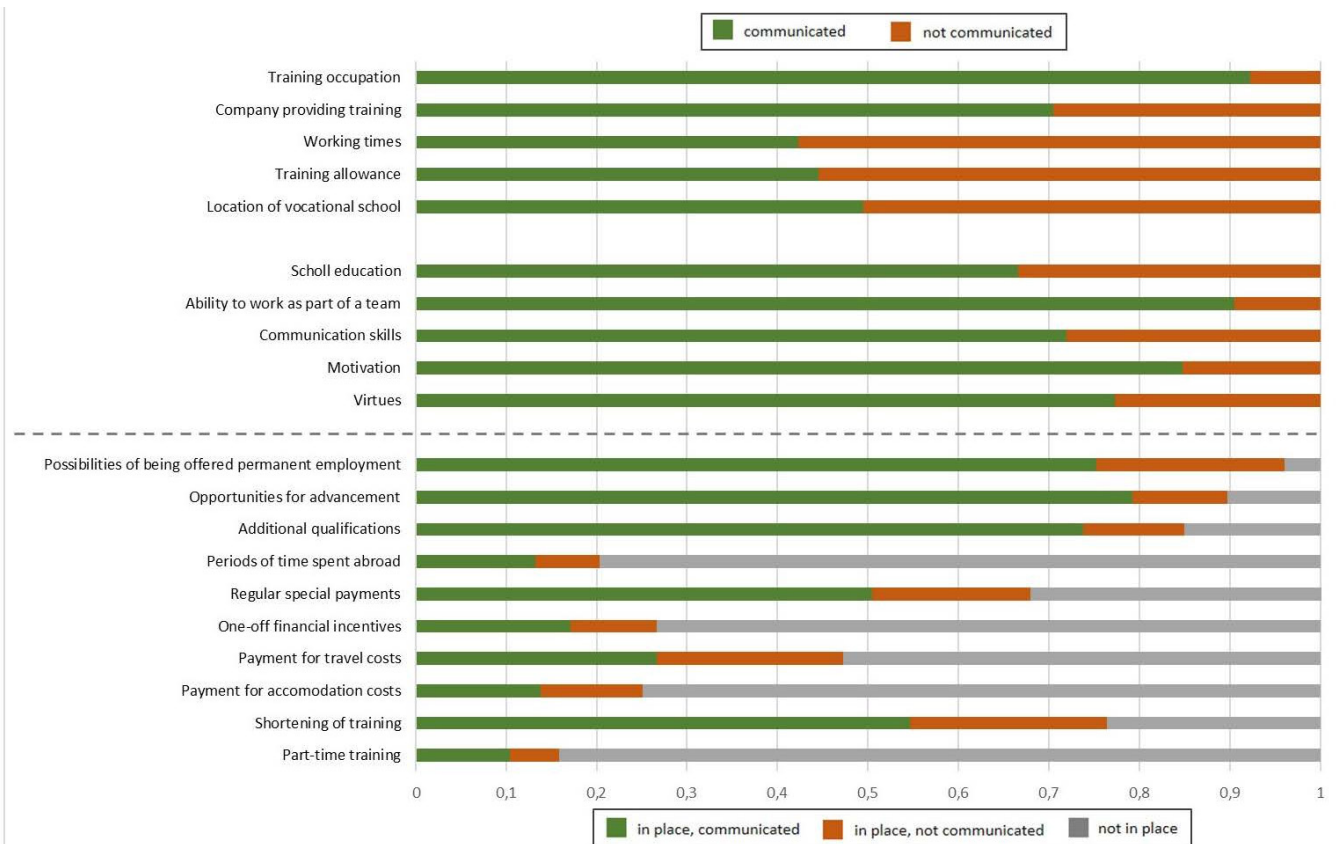

Fig. 2-A: Latent class 2 


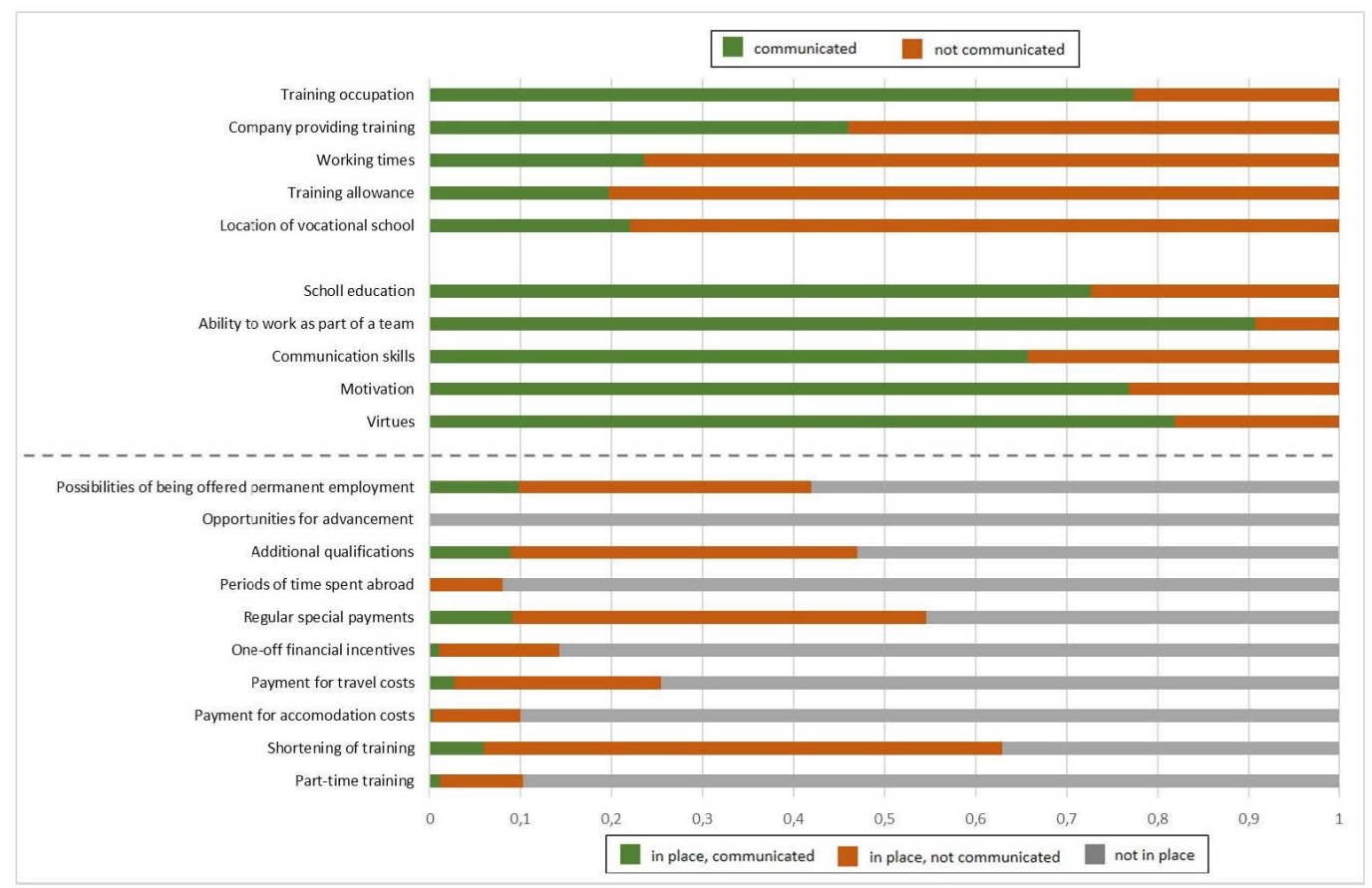

Fig. 3-A: Latent class 3

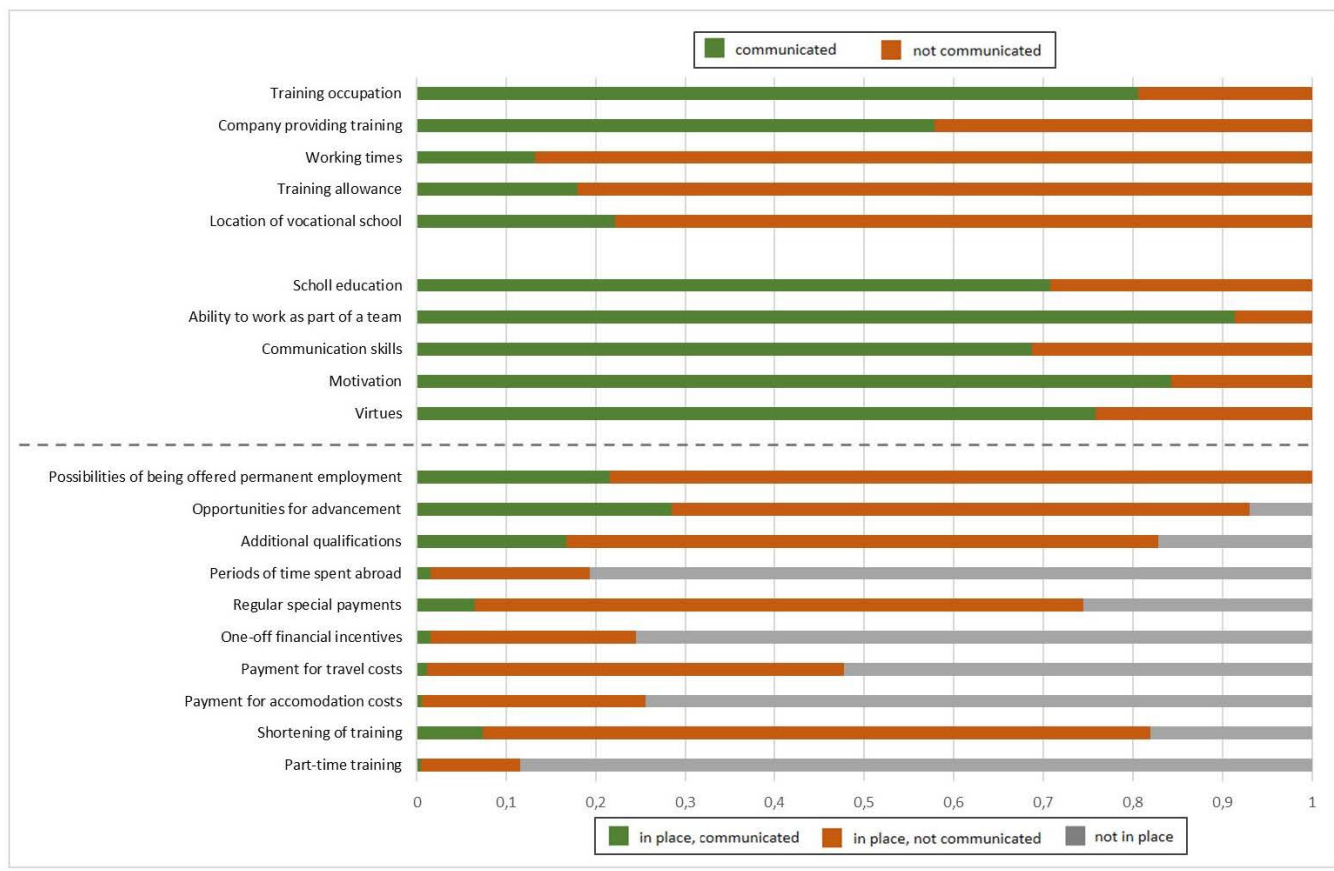

Fig. 4-A: Latent class 4 


\section{Biographical notes}

Dr Margit Ebbinghaus is an academic researcher at the Federal Institute for Vocational Education and Training in Bonn, Germany. Her focal areas of research are company participation in dual vocational education and training and the strategies adopted by companies for the recruitment of trainees. 